\title{
Kuhnian Correspondences in Contemporary Doctrinal Development Literature
}

\author{
PhD. Edwin El-Mahassni \\ $\mathrm{PhD}$ in theology through Flinders University, \\ AUSTRALIA \\ E-mail: elma0009@uni.flinders.edu.au
}

\begin{abstract}
Over the last few decades, there has been a plethora of literature that has analyzed and discussed the development of doctrine with much of it challenging the theories of Vincent and Newman. Some of the disagreements are not whether tradition should be a criterion or a factor, but rather to what extent it should be so. Coincidentally, just over fifty years ago, Thomas Kuhn, a philosopher of science challenged the traditional view through which science progresses. Opposing Karl Popper's assertions that science is completely objective, Kuhn believed that although it may follow long periods of stability and steady growth, occasionally there would be watershed moments which would completely revolutionize a particular field leading to a revaluation of long-established idea with not every reason attributed for these revolutions being neither rational nor scientific. Further, there has also been growing awareness in the literature of doctrinal development on factors which influence this progress in Christian teachings. In this paper, the aim is to understand the way some key aspects of Kuhn's work intersect with some of the contemporary theories in the development of Christian doctrine.
\end{abstract}

Keywords: Kuhnian Correspondences; Contemporary Doctrinal; Literature;

\section{Introduction}

Arguably the first treatise on the development of doctrine came from a French monk who sought to refute Donatism and Augustine. Written in 434, Vincent of Lerins authored the Commonitory. He believed that the Scriptures were the source of all authority yet knowing that there could be a myriad of possible interpretations, he argued that universal tradition should be a criterion in determining whether a doctrine should be accepted or not.[1]

It would be well over a thousand years before the theme of doctrinal development would again be rigorously tackled. In 1845, the ex-Church of England turned Roman Catholic theologian, John Henry Cardinal Newman, wrote An Essay on the Development of Christian Doctrine. Therein the aim was to refute the Reformation and affirm the Magisterium of the Roman Catholic Church and its teachings. He reaffirmed many of Vincent's thoughts and maintained the importance of tradition on the one hand, and skepticism of new doctrines on the other.

However, over the last few decades, there has been a plethora of literature that has analyzed and discussed the development of doctrine with much of it challenging the theories of Vincent and Newman. Some of the disagreements are not whether tradition should be a criterion or a factor, but rather to what extent it should be so. Coincidentally, just over fifty years ago, Thomas Kuhn, a philosopher of science challenged the traditional view through which science progresses. [2] Opposing Karl Popper's assertions that science is completely objective, Kuhn believed that although it may follow long periods of stability 
and steady growth, occasionally there would be watershed moments which would completely revolutionize a particular field leading to a revaluation of long-established idea with not every reason attributed for these revolutions being neither rational nor scientific.

Further, there has also been growing awareness in the literature of doctrinal development on factors which influence this progress in Christian teachings. In this paper, the aim is to understand the way some key aspects of Kuhn's work intersect with some of the contemporary theories in the development of Christian doctrine. Kevin Vanhoozer, Alister McGrath, Rhyne Putnam and Alan Thiselton are discussed and understood with respect to three crucial aspects identified by Thomas Kuhn with respect to scientific progress: the tension between tradition and the development of doctrine, the importance of interpretation in the development of doctrine and the role of communities in the development of doctrine.

For the first theme, Kuhn believed that the tension that exists between tradition and the progress of science is not explicitly stated and is implied in textbooks under assumed paradigms. [3] In science, there are problems which are stated where there are universally accepted solutions. However, the training that takes place in the student is to prepare him or her to solve problems for which there are no existing unequivocal answers. Kuhn wrote this paradoxical statement "the student requires a thoroughgoing commitment to the tradition with which, if he is fully successful, he will break."[4] Here, an analogy is made with Kuhn's views in this area to the development of doctrine.

Secondly, Kuhn also asserted that worldviews and paradigms play a major role in the development of doctrine. That is, scientific progress does not occur in a vacuum and so results are understood within a background of assumptions and axioms which a scientist brings into his or her work. As he noted "Scientific knowledge is embedded in theory and rules; problems are supplied to gain facility in their application.'"[5] Hence, problems and solutions in science take place within an understood framework which are presumed to be true. The manner by which interpretation takes in the formulation of Christian doctrine will also be investigated in relation to Kuhn's work.

Thirdly, Kuhn was one of the first philosophers of science to state that a community of practicing scientists is crucial in the way science progresses. It is a community who, through sheer weight of numbers, asserts the dominance of a particular paradigm so that any scientific progress is carried out under the auspices of a group of people who are in agreement over a core set of assumptions. This symbiotic relationship between paradigms and communities [6] is also analyzed with respect to the development of doctrine.

\section{The tension between tradition and the development of doctrine}

Thomas Kuhn's work is best known for positing that the progress of science is neither smooth nor free from controversy. Rather, although for the most part it steadily adds new knowledge and advances by the accumulation of new theories, there are times when revolutions take place. Science occurs under an overarching framework or paradigm which acts as a filter through which new results are to be interpreted. When new results appear and cannot be reconciled within this paradigm, then this can be thought of as an anomaly. A single anomaly on its own is not enough to cause a revolution which overthrows an existing paradigm. Rather, one anomaly might become two and two might turn into three and so on. When enough anomalies come to prominence, a crisis might ensue and a search for a new paradigm which can adequately account for the existing theories and the new anomalous occurs. 
Naturally, there is an inherent tension present if science does indeed take place in this manner. On the one hand, a dominant paradigm guides and influences the way research is conducted and results are to be understood. New theories do not tend to be surprising and rather they seek to strengthen the status quo and quash any potential dissenting views. Kuhn wrote

No part of the aim of normal science is to call forth new sorts of phenomena; indeed those that do not fit the box are often not seen at all. Nor do scientists normally aim to invent new theories and they are often intolerant of those invented by others. Instead, normal scientific research is directed to the articulation of those phenomena and theories that the paradigm already supplies.[7]

Thomas Kuhn believed that textbooks play an authoritative role in giving the impression that the progress of science has always been accumulating endeavor: "partly by selection and partly by distortion, the scientists of earlier ages are implicitly represented as having worked upon the same set of fixed problems...No wonder that textbooks and the historical tradition they imply have to be rewritten after each subsequent revolution." [8]

Tradition is also of great importance in Christianity, as is the authority responsible for upholding it. Gonzalez remarks "much of the history of Christian doctrine has been a struggle over tradition - that is, over the question of who is the true representative of tradition, and whose views uphold or deny the tradition."[9] McGrath is even more emphatic and echoes Kuhn's thoughts on the subliminal nature of history. He writes

The past, however, remains an obstinate aspect of the present. We do not live within a vacuum, but within a context, the intellectual, cultural and social contours of which have been shaped by the past... The influence of the past paradoxically, is at its greatest precisely when it is undetected or unacknowledged -when certain present day axioms and presuppositions, allegedly self-evident, in fact turn out to represent the crystallized prejudices of an earlier generation. [10]

Subsequently, McGrath proposes that a model which aims to describe doctrinal development must have the following four points: [11]

1. It will be descriptive, not prescriptive so that it is based on the historical study of Christian theology without reference to any preconceived notions.

2. It will acknowledge the parallels between the episodic and discontinuous development of scientific theories, and the development of Christian doctrine.

3. It avoids foundationalist assumptions.

4. It recognizes that the developmental pressures which may be identified can point in different directions, sometimes leading to different local outcomes, or occasional appearances of stagnation or retrogression.

An existing paradigm must allow and even encourage new and unprecedented results which are completely unexpected. Again, Kuhn wrote "... and this is the point- the ultimate effect of this tradition-bound work has invariably been to change the tradition. Again and again the continuing attempt to elucidate a currently received tradition has at last produced one of those shifts in fundamental theory...'[12] Wiles was perhaps the first person to note a parallel with Kuhn's scientific revolutions and the way doctrines develop.[13] He also described the issue of development of doctrine yet the need to safeguard it against subjectivity. He proposed that perhaps the unifying thread is that there is a continuity of doctrinal aims. [14] Wiles wrote with respect to the Church Fathers "Their doctrinal affirmations were based upon an appeal to the record of Scripture, the activity of worship, and the experience of salvation." [15] Yarnell notes that while tradition was fixed 
in the apostolic age, there is the work of the Holy Spirit which also means that the Scriptures are not merely relegated to a historical account. He maintains "Although the revelation is affixed to the Bible, its illumination by the Spirit is dynamic in that it is not limited to previous perceptions. And yet there should also be a deep respect for the work of the one Spirit in the entire history of the Churches of the one Christ..."[16] Yarnell has a deep respect for the infallibility of the Scriptures but understands that there is a dynamic aspect which must be present in the way the Scriptures are revealed to a believer. A very recent book by Putnam notes this is of fundamental importance for understanding the development of Christian doctrine

If history is any indication, postcanonical doctrinal development is an inevitable reality in the Christian theological tradition. But such development can also serve as a significant threat to the identity and continuity of the received tradition. Can theology present expressions of belief and remain faithful to the unique authority and sufficiency of the Bible? More practically, can the contemporary systematic theologian address current crises and still maintain continuity with biblical faith? The theologian who takes up the socalled problem of doctrinal development assumes that God has once and for all revealed himself through the medium of human language in Scripture and must by some means explain how Christian doctrines, which purport to be grounded in this revelation, continue to grow or develop even after the epoch of canonical revelation is closed. [17]

Putnam gives a detailed summary of Thiselton and Vanhoozer's work on doctrinal development and remarks that while Thiselton provides a descriptive account of doctrinal development, Vanhoozer's work is normative in nature. For Thiselton, against the backdrop of truth claims about the nature of God or biblical history, situations arise which require new responses or ways of taking a stand. [18] Framing these beliefs in terms of dispositions, these are difficult to change and can be multifaceted and do not merely involve the individual but are also communal. [19] This resistance to change, according to Putnam, is what allows for continuity in development. Commenting on Vanhoozer, Putnam notes that continuity exists because of its missiological criterion and write "Doctrines may grow or develop in ways that are not exact duplications of past formulations, but they may retain continuity or identity in a shared mission found the gospel of the triune God."[20] In conjunction, there is impact of culture in preserving doctrine. Under the assumption that different cultures have rules of law and other stable norms, then this aids the continuity of doctrine. [21]

For Christianity, if one is to strictly define paradigms only in the way that Hans Küng describes them, [22] then not much of an argument can be mounted for there being a continuity of doctrine.[23] On the other hand, if the paradigm is that of orthodox Christianity then clearly the Scriptures are at least an everlasting source for the development of doctrine. Vanhoozer has taken a novel approach in describing the role of doctrine and asks individuals to engage in the "drama" of what God is doing to renew all things in Jesus Christ. He insists "On the one hand, if doctrine does change, what criteria can we use to distinguish legitimate developments from heretical distortions?"[24] Although, like Yarnell, he affirms the foundational authority of the Scriptures, he nevertheless maintains that "Doctrine's direction must therefore be susceptible of fresh appropriations in new culturalhistorical settings.'[25] The tension already highlighted by Kuhn with regards to science also seems to be present in the way doctrine should be communicated and expounded upon in Christianity. 
Vanhoozer also expands on the work of Lindbeck who believed non-theological issues, which were cultural and social in nature, have led to an emphasis of individual religious to the detriment of traditional propositional understandings of religion. [26] Apart from the cultural appeal, a benefit in highlighting these factors are that they allow for interreligious dialogue by encouraging the expression of symbols as evidence of an ultimate, unifying reality. However, the problem is that such an approach can quickly descend into a relativistic morass. Aside from being subjective, they are also restricted to a place or time. Lindbeck noted that despite some Roman Catholic theologians' efforts in trying to meditate a middle ground so that transcendental experiences must be normative (e.g. the Bible), there is a growing gap between these experiential expressivist forms and the more theological approaches.[27] Vanhoozer also makes the Bible the starting point of doctrine but recognizes that doctrine is a multidimensional task that involves historical, literary and ideological approaches [28].

Thiselton also discusses this problem but has a slightly different take on what is the root of the tension. He briefly mentions the work of Küng and Tracy[29] and asserts that this essentially boils down to the problem of a dialectic between theory and praxis[30]. Thiselton expresses the importance of a community[31] and in the end seems quite content with letting a plurality of voices from the Bible speak on their own without artificially trying to harmonize them; and yet this does not mean that they are contradictory. Thiselton writes

Two points are especially important for a hermeneutics of doctrine. First, the canon is not artificially contrived set of books awaiting a decision or imprimatur from the third or fourth centuries...Second, the writers in question (of Canon and Biblical Interpretation) demonstrate their respect for the integrity of specific voices without attempts at artificial harmonization, and let the interaction between different viewpoints speak together as different (but not contradictory) voices. [32]

But, this plurality of voices emanating from the Bible must ultimately be understood by human beings with particular worldviews. It might be the case that for a considerable period of time, a particular worldview prevails and ultimately silences other voices which are just as valid or justifiable. For instance, Thiselton cites the example of Ecclesiastes and Job being different yet complimentary to Deuteronomy and Proverbs with regards to providence.[33] But, a person or a group of people going through incredible hardship might relate much more with Job than Proverbs, but someone who is perhaps not going through fiery trials but is seeking more wisdom might be tempted to read more on the vignettes that Proverbs offers. A particular situation or context renders itself much more likely to a particular Scripture than another. Hoyningen-Huene, in analyzing the work of Thomas Kuhn, makes the interesting point that the concept of incommensurability in scientific paradigms might have been misunderstood.[34] It is easy to see how Kuhn's words on the nature of competing paradigms, namely "the competition between paradigms is not the sort that can be solved by proofs" [35] might be taken to mean that this implies discontinuity between paradigms. However, Hoyningne-Huene believes that this is a misunderstanding because after a revolution, some parts of normal science remain. [36] Hence, again continuing with the example of Job and Proverbs: a particular season might lend itself to a reader identifying with the sufferings of Job; and yet better times do not mean that what was learned or gleaned from reading that book imply those insights are now false or invalid.

Yarnell stressed the ultimate authority of Scripture and its sufficiency. The presence of the Holy Spirit, assumes that though variety exists among individuals, there is a unity and 
a common understanding. Vanhoozer, following on the work of Lindbeck, discusses the importance of a given culture to portray and give a voice to the Scriptures but with due consideration to the different possible approaches. Thiselton remarks that the different voices present in the Scripture do not constitute the presence of contradictions but rather the importance of context within which each takes place. In short, for Christianity, a shared rational understanding, endowed by the Holy Spirit, allows for the development of doctrine and for the flexibility of historical context, both in terms of the writers of different parts of the Scriptures and with respect to the different interpretative approaches, to be taken into account. This statement which takes on the different aspects that each writer identified underlines not only a plurality but also a commonality. Van Huyssteen echoes this sentiment and believed this is possible because of a common rationality, i.e. "The fact that the rich resources of human rationality are shared by and significantly overlap in scientific and theological rationality, as identified in the quest for optimal understanding, responsible judgment, and progressive problem-solving..."[37] This point by Van Huyssteen is also one that is shared by Hoyningen-Huene who discusses another common misunderstanding with regards to incommensurability, namely that incommensurable paradigms are incomparable. He writes

Any juxtaposition of the two theories must have a holistic character, in the sense that all theoretical moments, hence all differences must be considered more or less simultaneously. To be sure, some facts may be formulated in one theory but not in the other. Yet the holistic comparison of the potentials of the two theories is not thereby ruled out.[38]

If this applies to the development of doctrine, then this suggests the presence of both continuity and fixity. There is fixity because two paradigms can only be compared if there is at least a point of commonality, and there is obviously continuity because a change in paradigm allows for the integration of anomalies which were not previously possible and for the development of "normal science" which would not have been normal under the previous paradigm. The existence of a paradigm, nevertheless, gives rise to another key element in the development of doctrine, namely, interpretation.

\section{The Importance of Interpretation for Development of Doctrine}

The influence of interpretation and communication on the development of doctrine has already been mentioned to some degree in the previous section. Of course, varying and different approaches to hermeneutics might open a Pandora's Box and invite the charge of relativism. It is interesting that this same accusation has also been labeled at Thomas Kuhn with regards to his views on the way science progresses. He writes, with some lament

...my views, it is said, make of theory choice "a matter for mob psychology". Kuhn believes, I am told, that "the decision of a scientific group to adopt a new paradigm cannot be based on good reasons of any kind, factual or otherwise." The debates surrounding such choices, must, my critics claim, be for me "mere persuasive displays without deliberate substance." [39]

Even though he goes on to describe criteria such as accuracy, consistency, scope, simplicity and fruitfulness as suitable for determining the adequacy of a theory, these do not seem to have abated his detractors. If they are right about Kuhn, then a consequence would be the presence of complete discontinuities present in the development of doctrine. Yet, as already mentioned, this does not seem to bear true. McGrath suggests that doctrine far from being a subjective and culturally dependant endeavor; it is rooted in history and tradition. 
Christian doctrine may be regarded as the present outcome of that long growth of tradition in which the Christian community has struggled to arrive at an interpretation of its foundational traditions, embodied in the New Testament, which both does justice to its own present place in tradition, and attempts to eliminate those doctrinal pre-judgments which are to be judged as inadequate. It is a historical phenomenon, grounded in history and conscious of its own historicity. [40]

Nevertheless, in case this implies doctrine is stale, McGrath also notes that "doctrine is an activity, a process of transmission of the collective wisdom of a community, rather than a passive set of deliverances." [41] When one thinks of doctrine in this manner; as a context dependant exercise but which is anchored in its history and past, then that frees Christianity from the shackles of traditionalism for its own sake but also from the dangers of socio-cultural factors overstretching their impact on the Church. He also lists three criteria for the development of doctrine. These are: 1) doctrine is a social demarcator, 2) doctrine is generated and interpreted by the Christian narrative, 3) doctrine interprets experience and 4) doctrine makes truth claims. [42] Before McGrath, Toon also maintained every Church and denominational doctrine is "historically and culturally conditioned."[43] Doctrine is not created in a vacuum by gleaning the Scriptures without reference to society and the culture around it. Rather, doctrine is historically molded as a response to questions put to the Church. This means the same truth is viewed differently according to different perspectives and circumstances so that development is not in the form of regular organic growth, but it is rather complex and intricate. Yarnell, however, criticized both McGrath and Toon in that they elevate either tradition and/or rational theories as necessary to supplement the Scriptures. And although Yarnell commends the fact they allowed a place for Christ and the Scriptures, he believes they are weak in the roles pneumatology and ecclesiology play in doctrinal formulations. [44]

Vanhoozer described the process of interpreting and understanding doctrine as being a drama. Citing Serene Jones, he writes "Doctrines are "like loose but nonetheless definitive scripts that persons of faith perform; doctrines are the drama in which we live out our lives."[45] There is a constant interaction between texts and not only the way those texts are understood but also lived out in a believer's everyday life. It is interesting that just like Thiselton, he also mentions the theory/practice dichotomy by noting that this way of viewing drama is a way of overcoming that problem. Vanhoozer again notes

The drama stems from the clash between ideology (read: theology) of the text and that of the reader, on the one hand, and from the conflict of disciplinary approaches, methods, and rival ways of reading the text, on the other. One goal of the present work is to model a post-critical approach to biblical interpretation that respects both the principle- or rather, practice - of sola scriptura and the location of the interpretive community that nevertheless results in performance knowledge and doctrinal truth. [46]

Of course, not all Christian denominations will ascribe to sola scriptura - the principle that the Bible or Scriptures should be the sole rule of faith, but they all would agree that there is an unshakable and unquestioned authority. This definitive authority and the teachings that they carry must be interpreted and lived out by real people. For Putnam, authority is crucial in the way a text is to be interpreted. They act as a guide towards determining what is heterodoxy and heresy.[47] Evangelicals take Scripture as their primary source, while Roman Catholics defend the ecclesial tradition embodied in councils, as well as the papacy being a supplement to revelation.[48] This is linked to establishing a worldview which is shared across a community and "provides a frame of reference to 
develop new knowledge and understandings." [49] However, the Christian faith is more than a mere set of propositions. It is a faith that is lived out and practiced so that, according to Putnam, the development of doctrine should not be reduced to a single strategy or method.[50] Nevertheless, Putnam believes that doctrinal development has much in common with the natural sciences. Using Kuhnian terms, Putnam notes "Doctrinal statements, like scientific theories, may strive for reality depiction but also like scientific theories, they are corrigible or open to revision and correction if deemed necessary.'[51] And while both science and theology work within frameworks of belief and, in accordance with McGrath and Van Huyssten, even though in both domains "models or theories may grow, change, or be discarded"[52], they are trying to articulate scientific and theological realities respectively.

In science, the emphasis of "living out" a theory is understandably either nonexistent or rather trivial. However, an analogy can be made with the way scientific theories are or are not distinct from observations. Any struggle to reconcile both of these aspects of science would mirror the mentioned difficulties of theory and praxis in the development of doctrine. Hoyningen-Huene, in discussing Kuhn's work, rather than focus on this binary categorization, instead discusses ways of learning concepts [53]. He remarks that when laws and theories are used to help with concept learning, a student will typically apply that law in a specific situation and then seek to apply those laws to other analogous contexts: "These similarities permit the specification of the law-schemata for new situations by analogy with the specifications of appropriate to familiar situations. In other words, they make it possible to apply the concepts occurring in the schemata to new problem situations."[54] The scientist although, he or she is using theoretical concepts well-established, nonetheless appropriates those learned methods and techniques in a manner which is particular to the problem that is currently being tackled. There is an interpretation of a general principle and concept that is applied in a specific manner.

Recall Yarnell highlights a person's freedom to read the Scriptures by him or herself and understand them with the aid of the Holy Spirit and God-given intellect, which again speaks of a shared paradigm or worldview from which the Scriptures are interpreted. And, by citing Marpeck, Yarnell employs the writings of an English Methodist historian as an exemplar of the views of Free-Church historians to describe development of doctrine. Interestingly, this subtly showed that in formulating doctrine, there are factors that are outside of Christianity which are crucial. That is, Yarnell's selective use of previous theologians' work to support a particular view of doctrinal development shows that it is not only bolstered through proofs or evidences, but it is also guided by motives.[55] Indeed, it could be argued that Vanhoozer's use of the Bible as the founding cornerstone by which doctrine should proceed also reveals his personal biases and preferences, even if he does go to great lengths to stress the importance history, interpretation and culture play in the way a doctrine is to be communicated and lived out.

Culture is indeed important and shapes interpretation of particular texts or situations. Lindbeck described a cultural-linguistic approach which takes into account the importance of culture but does not elevate it to an authoritative status. The cultural-linguistic approach advocated by Lindbeck, defines religion as an idiom. It is a guide, rather than a set of regulations which set out in hard and fast rules what is or is not permissible. He remarked:

A religion can be viewed as a kind of cultural and/or linguistic framework or medium that the entirety of life and thought... It is not primarily an array of beliefs about the true and the good (though it may involve these), or a symbolism expressive of basic 
attitudes, feelings, or sentiments (though these will be generated). Rather, it is similar to an idiom that makes possible the description of realities, the formulation of beliefs, and the experiencing of inner attitudes, feelings, and sentiments. Like a culture or language, it is a communal phenomenon that shapes the subjectivities of individuals rather than being primarily a manifestation of those subjectivities. [56]

The cultural-linguistic approach must be able to "...handle anthropological, historical, and another non-theological data better than do the alternatives..."[57] This model appears to place some boundaries on the extent human experience is shaped and molded because it is constrained by cultural and linguistic factors. Vanhoozer, however, disagrees with Lindbeck on this point. Vanhoozer believes that Lindbeck places too much emphasis on community practice and downgrades the standing that the Scriptures should take. The question here is the basis or the foundation or authority by which interpretation should take place, not whether interpretation should take place at all. Vanhoozer writes:

The aim of Lindbeck's cultural-linguistic approach is to initiate persons into and preserve the set of grammatically correct linguistic practices that structure the life of the church and shape Christian identity...In Lindbeck's regulative theory, doctrine does not direct community but is directed by it. Doctrine stands in a second-order relationship not to Scripture but to the use of Scripture in the church. What seems to matter most in culturallinguistic theology is "socializing" persons into a set of authoritative communal practices[58]. According to Putnam, Thiselton borrows much from Thielicke with respect to authority. On the one hand, Thiselton is respectful of authority, but asserts the authority of the self in determining what is true for the present." [59] This also means that hermeneutics is paramount to Thiselton. In fact, Putnam asserts that for Thiselton experience is hermeneutical. Interpretation cannot be planned or be deliberate by method and is an exploration of what it means to be human.[60] And for Thiselton, the hermeneutics of doctrine has a transformative effect on the interpreter and the believer. He writes:

Biblical hermeneutics explores levels of meaning, strategies of reading, historical distance, appropriation, engagement, and formation, and often features patient and attentive listening...Can these habits of mind, with the historical, intellectual, and moral resources of hermeneutics, be placed at the service of understanding, exploring, appropriating, and applying Christian doctrine? [61]

Yarnell focuses on the Spirit's role in developing doctrine which is based on an infallible source - the Scriptures. Vanhoozer stresses the importance of culture, while Thiselton believes that experience and an individual's reception of it are critical in the development of doctrine. All of these may not agree with one another, however, they all underscore the impact of non-rational or contextual factors in understanding the way doctrine develops.

Kuhn also understood that interpretation was very important in the way science progresses. He maintained that this can only be done through the lenses of a paradigm.[62] When a paradigm changes through a revolution, this cannot be fully explained by reinterpretation. [63] This does not mean that interpretation does not occur, but only that the constraints imposed by a person's paradigm, may limit extravagant developments and thus constant upheaval. However, Christianity does not merely exist within merely an individual's mind. The body of believers is often referred to as the Church and as such the role of the Christian community is paramount; and this is now discussed next. 


\section{The Role of Communities in the Development of Doctrine}

Kuhn had a lot to say on the role that communities play in scientific progress. He believed that in order for science to advance and accumulate new theories, there is a group of people that take charge and steadily come up with novel results. However, these results are not revolutionary and are not unexpected. They are all conducted within a paradigm which provides a set of rules and axioms through which all research is to be conducted.

In the development of doctrine, there are theologians who state that this is the also the case. In fact, McGrath believes that this social aspect is what demarcates doctrine from theology:

...it will be clear that the distinction between 'doctrine' and 'theology' serves to emphasize the social function associated with the former, yet denied to the latter. Doctrine identifies social communities. Ecclesial bodies may indeed 'receive' - in the technical sense of the term - theologies, thus altering their status to that of doctrine: this process of reception, however...takes place at the communal, not the individual, level. Theology may be received as doctrine; without reception, it remains theology [64]. Hence, doctrine defines a community which receives and takes it as given an interpretation of a Christian narrative or experience. [65] Vanhoozer makes a similar distinction when he writes "Theology here becomes a matter of ecclesial self-description, of unpacking the implicit logic of Christian worship, doctrine, and ethics. Doctrines are thus, to paraphrase Schleiermacher, accounts of the church's corporate expressions set forth in speech." [66]

McGrath, again, also expresses a similar sentiment and goes into more detail in attempting to describe the role of social constructs in developing doctrine and makes the following points:[67]

1. At least some aspects of the process of doctrinal development and reception are socially constructed.

2. Social constructs are subject to constant reappraisal and revision in the light of advancing knowledge and experimental observation.

3. A realistic approach to God or to the world is not called into question through the recognition of socially constructed aspects of the theories developed by either Christian theology or the natural sciences.

Thiselton also argues that "doctrine carries with it inextricably a communal commitment and communal formation." [68] The parallels with Kuhn's depiction of what constitutes scientific communities are obvious when he noted:

A scientific community consists, on this view, of the practitioners of a scientific specialty. To an extent unparalleled in most other fields, in the process they have undergone similar educations and professional initiations; in the process they have absorbed the same technical literature and drawn many of the same lessons from it. [69]

While Vanhoozer affirms the importance of the Church as a community, he is, however, quick to point out that this community will have rules and behaviour only as far as it conforms to the Scriptures.[70] Yet, this community is indispensable since "without a people to embody it (the holy script), the script lacks something essential, for the canon "delivers its meaning only as it is 'played out' in patters of human action in Church and society.'[71] These rules and behaviour which Vanhoozer depicts are analogous to the paradigm by which a group of scientists would work under. Similarly, Kuhn noted "scientists...require criteria to tell them which particular symbolic version should be applied to which problem, and these criteria, like the correlation rules that are said to 
transport meaning from a basic vocabulary to theoretical terms, would be a vehicle for empirical content." [72]

Yarnell describes a congregationalist view on the way the Church should be run. Hence, it is not surprising that he takes a very egalitarian and inclusive position in how doctrine should be developed. Recalling the work of Marpeck, he writes "...their (as in the congregation as noted by Marpeck) belief that the Spirit broke to the entire community as it read Scripture together encouraged Anabaptists to seek conversation with other Christians. Theology, for them, was always done best in communal Bible study... The Anapbatists seemed more than willing to enter debates with the state church theologians, even when it led to persecution." [73] Of course, however, the assumption was that this was always done by appealing to the authority of Scripture.

McGrath is well aware of the role that a community has in balancing an earlier section: the tension between the need to preserve or continue the past and that of developing doctrine to make it relevant for a given time and place. He notes that the preservation of the Christian tradition rests on the shoulders of a community when he writes:

The past generated a tradition to which the present is heir. That tradition involves modes of discourse, ways of conceiving the world, and so forth, which it impressed upon the world, and which was perpetuated in a definite historical form, being mediated through both institutions and individuals. A community arises as the bearer of this tradition, thus establishing its continuity over extended periods of time. Those standing within this tradition detect a resonance of values, language and concepts with the past, in that their outlook has been shaped by a community tradition precipitated by the past. [74]

Hence, for McGrath, the tradition and the history of Christianity serves as a paradigm for the community. It is the framework for which doctrine may or may not develop. In specific Kuhnian terms, "the values, language and concepts" serve as the instrumental commitments by which can be legitimately used to carry out research.[75] There is feedback loop mechanism which is also present between doctrine and social communities. On the one hand, social constructs, as noted earlier, play a role in developing doctrine; but on the other, doctrine may also function as a social demarcator so that it "...enhances the sense of identity of a community, and facilitates its distinction from other communities."'76] However, McGrath, is also of the opinion that while this may have occurred throughout the history of Christianity, the possibility of seeing doctrine function as social demarcators between ecclesial traditions, then ecumenical approaches might be possible. [77]

McGrath, however, is not a propositionalist. He does not believe that all doctrine can be neatly derived from the past through these rules and guidelines. There is also a place for doctrine as an interpretation of experience. He recalls Schleiermarcher's thoughts that "the continuity of Christianity is to be established at the experiential level of the Christian community... and articulated in a purely descriptive manner at the level of doctrine." [78] An emphasis or stress on the importance of interpreting experience as a means of doctrine can have an analogy in the sciences. The first is that of logical empiricism. Also known as verificationism, it is the idea that statements verifiable either logically or empirically would be cognitively meaningful. Rejected later on by philosophers such as Gödel and Popper, Kuhn also dismissed this idea on the basis that there might not be "a complete and full account of nature."[79] This is not to say that Kuhn rejected truth, rather he repudiated the notion that there was a correspondence between true statements and facts about the world. 
The implication is that even if an entire community agrees on a particular scientific theory, or in this case, a doctrine, this does not meant that it corresponds to an actual fact.

Putnam has also recently mentioned Kuhn within the context of theology.[80] Noting a parallel between scientific revolutions and the role of hermeneutics, the role of rationality is "an interpretative framework established by local, historically situated communities of knowledge for the purpose of theorization." [81] Recalling also Thiselton, doctrinal development occurs between the two extremes of an "authoritative corporate memory and its critical appropriation or analysis."[82] That is, there are social and historical aspects which play a part in determining the way doctrine is developed. And although "distinctives of her theological tradition inevitably color her process" [83], this "takes place in light of the limitations and/or advantages posed by her own view of a doctrinal topic." [84] Putnam believes that for Vanhoozer, the importance of community is more authoritative than the text itself, because it is the performance of the community ultimately establishes the meaning and belief of the community.[85] Vanhoozer is not so naive as to believe that there will always be a single possible interpretation, and in fact, it is this potential plurality that can allow for doctrinal development. [86] However, it must be remembered that this can also lead to the introduction of heresies and doctrinal corruption. Hence, not all interpretations are equal, but even then, these can, ironically, be rejected by the exposition and development of true doctrinal development.[87] Putnam also demonstrates that the role of communities intersects with tradition and interpretation, the previous two sections.

Perhaps the question comes back not to a theory of correspondence between facts and experience, but rather what is the true source of authority by which all theories and experiences should be grounded on. Although Vanhoozer does place the Scriptures above tradition, he does not relegate the latter as unimportant. He presents an interesting take on their respective roles: in his analogy as doctrine as drama, he posits that the Scriptures are the 'script' and tradition is the performance. [88] In this context, tradition rather than living in the past, it is a performance and is made dynamic by a community.[89] The role of tradition as a performance is put by Vanhoozer in the following manner:

Scripture may be self-interpreting, but it does not perform itself. The principles of general hermeneutics alone do not tell us how, for example, to relate Old and New Testament, or for that matter, how to bring Scripture to bear on contemporary bioethics. This is neither the thrust nor the intention of sola scriptura. On the contrary, sola scriptura stands for a certain church practice, a certain way of using Scripture in the church. Some have rushed to the conclusion, therefore, that it is a certain way of using the Bible, and not the Bible itself, that is authoritative. What ultimately counts is the performance, not the script.[90]

This apparent relegation or subjugation of tradition to Scripture may not be satisfactory to Roman Catholics. But, Vanhoozer is a Reformed Presbyterian theologian and to even suggest that tradition not only has a part to play in Christianity, but is also a necessary component to be played by the Church community seems to be quite a remarkable concession on a controversial aspect arguably thought of at best unimportant, and at worst heretical, to the Reformed denominations. Yet Vanhoozer does not believe that affirming tradition in this manner downplays or lowers sola scriptura.

Recent literature in the development of criteria has reaffirmed the importance of a practicing community in the formulation of new teachings. Theologians like McGrath and Vanhoozer have stressed different aspects with regards to a community's role: McGrath 
believes that it is the communal facet that distinguishes doctrine from theology, while Vanhoozer maintains that the community is critical in the performance of the Scriptures; and Thiselton also remarks that "doctrine is not a matter of monologic discourse produced by a single person and addressed to individuals in abstraction from corporate worship and the life of the church." [91] Further, as has been demonstrated, the role of the community does not exist in isolation to the need to balance tradition with development and the way a text is interpreted to develop doctrine.

\section{CONCLUSION}

Kuhn's Revolutions were written over 50 years ago and applied to the way science progresses. Here, it has been shown that his ideas can be applied to the modern and contemporary literature in the development of doctrine. The tension between long-standing tradition and the need to develop new teachings; the role that a particular text is interpreted and the importance of practicing communities have been identified as influential by theologians who seek to understand doctrinal development. Further investigation, for example, could also concentrate on contrasting and comparing the importance of tradition between the sciences and theology. Another interesting study could also focus on whether, just like in the sciences, there exists a single dominant worldview for a particular doctrine or rather there is a plurality of voices which would be equivalently accepted as orthodox Christianity.

\section{REFERENCES}

[1] Justo L. Gonzalez, A Concise History of Christian Doctrine (Abingdon Press: Nashville, 2005), 195.

[2] Thomas S. Kuhn, The Structure of Scientific Revolutions, 4th ed. (Chicago: The University of Chicago Press, 2012).

[3] Thomas S. Kuhn, The Essential Tension (Chicago and London: The University of Chicago Press, 1977), 229.

[4] Ibid., 235.

[5] Thomas S. Kuhn, The Structure of Scientific Revolutions, 4th ed. (Chicago: The University of Chicago Press, 2012), 187.

[6] Ibid., 175.

[7] Thomas S. Kuhn, The Structure of Scientific Revolutions, 4th ed. (Chicago: The University of Chicago Press, 2012), 24.

[8] Ibid., 137.

[9] Justo L. Gonzalez, A Concise History of Christian Doctrine (Abingdon Press: Nashville, 2005), 195.

[10] Alister McGrath, The Genesis of Doctrine (Various: William B. Eerdmans Publishing Co and Regent College Publishing, 1990), 82.

[11] Alister E. McGrath, Scientific Theology : Volume 3: Theory (T \& T Clark: London, 2003), 219.

[12] Thomas S. Kuhn, The Essential Tension (Chicago and London: The University of Chicago Press, 1977), 234.

[13] Maurice Wiles, The Making of Christian Doctrine (Cambridge University Press: Various 1978 (1967)), 169-71.

[14] Ibid., 173.

[15] Ibid., 173.

[16] Malcom B. Yarnell III, The Formation of Christian Doctrine (Nashville, TN: B \& H Academic, 2007), 138.

[17] Rhyne R. Putnam, In Defense of Doctrine: Evangelicalism, Theology and Scripture (Minneapolis, MN: Fortress Press, 2015), 38-9.

[18] Ibid., 332-3.

[19] Ibid., 340. 
[20] Ibid., 342.

[21] Ibid., 343.

[22] H. Küng, Theology for the Third Millenium: An Ecumenical View (New York: Anchor Books, 1990), 129, 139-61. Hüng merely describes paradigms as neatly distinct epochs of Christian history distinguished by a predominant worldview at any given time.

[23] R. P. C. Hanson, The Continuity of Christian Doctrine (New York: Seabury Press, 1981), 72.

[24] Ibid., 111-2.

[25] Kevin J. Vanhoozer, The Drama of Doctrine (Louisville, KY: Westminster John Knox Press, 2005), 111.

[26] George A. Lindbeck, The Nature of Doctrine (Philadelphia: The Westminster Press, 1984), 21-2.

[27] Ibid., 24-5.

[28] Kevin J. Vanhoozer, The Drama of Doctrine (Louisville, KY: Westminster John Knox Press, 2005), 18.

[29] Hans Küng, Hans and David Trac (eds). 1991. Paradigm Change in Theology, trans. Margaret Kohl. New York: Crossroad.

[30] Anthony C. Thiselton, The Hermeneutics of Doctrine (Grand Rapids, MI; Cambridge: Wm. B. Eerdmans Publishing Co, 2007), 119-20.

[31] The importance of a community will be addressed later in much more detail.

[32] Anthony C. Thiselton, The Hermeneutics of Doctrine (Grand Rapids, MI; Cambridge: Wm. B. Eerdmans Publishing Co, 2007), 144.

[33] Ibid., 143-4.

[34] Paul Hoyningen-Huene, Reconstructing Scientific Revolutions (Chicago and London: The University of Chicago Press, 1993), 222.

[35] Thomas S. Kuhn, The Structure of Scientific Revolutions, 4th ed. (Chicago: The University of Chicago Press, 2012), 147.

[36] Paul Hoyningen-Huene, Reconstructing Scientific Revolutions (Chicago and London: The University of Chicago Press, 1993), 222.

[37] J. Wenzel Van Huyssteen, The Shaping of Rationality: Toward Interdisciplinarity in Theology and Science (Grand Rapids \& Cambridge: W. B. Eerdmans, 1999), 181.

[38] Paul Hoyningen-Huene, Reconstructing Scientific Revolutions (Chicago and London: The University of Chicago Press, 1993), 221.

[39] Thomas S. Kuhn, The Essential Tension (Chicago and London: The University of Chicago Press, 1977), 321.

[40] Alister McGrath, The Genesis of Doctrine (Various: William B. Eerdmans Publishing Co and Regent College Publishing, 1990), 12.

[41] Ibid., 11.

[42] Ibid., 37.

[43] Peter Toon. The Development of Doctrine in the Church. (California: Wm. B. Eerdmans Publishing Co., 1979), 81.

[44] Malcom B. Yarnell III, The Formation of Christian Doctrine (Nashville, TN: B \& H Academic, 2007), 126-7.

[45] Kevin J. Vanhoozer, The Drama of Doctrine (Louisville, KY: Westminster John Knox Press, 2005), 18.

[46] Ibid., 19.

[47] Rhyne R. Putnam, In Defense of Doctrine: Evangelicalism, Theology and Scripture (Minneapolis, MN: Fortress Press, 2015), 210.

[48] Ibid., 211-2.

[49] Ibid., 227.

[50] Ibid., 294.

[51] Ibid., 306.

[52] Ibid., 306.

[53] Paul Hoyningen-Huene, Reconstructing Scientific Revolutions (Chicago and London: The University of Chicago Press, 1993), 93.

[54] Ibid., 104.

[55] Malcom B. Yarnell III, The Formation of Christian Doctrine (Nashville, TN: B \& H Academic, 2007).

[56] George A. Lindbeck, The Nature of Doctrine (Philadelphia: The Westminster Press, 1984), 33. 
[57] George A. Lindbeck, The Nature of Doctrine (Philadelphia: The Westminster Press, 1984), 30.

[58] Kevin J. Vanhoozer, The Drama of Doctrine (Louisville, KY: Westminster John Knox Press, 2005), 96-7.

[59] Rhyne R. Putnam, In Defense of Doctrine: Evangelicalism, Theology and Scripture (Minneapolis, MN: Fortress Press, 2015), 146.

[60] Rhyne R. Putnam, In Defense of Doctrine: Evangelicalism, Theology and Scripture (Minneapolis, MN: Fortress Press, 2015), 129-30.

[61] Anthony C. Thiselton, The Hermeneutics of Doctrine (Grand Rapids, MI; Cambridge: Wm. B. Eerdmans Publishing Co, 2007), xx.

[62] Thomas S. Kuhn, The Structure of Scientific Revolutions, 4th ed. (Chicago: The University of Chicago Press, 2012), 122.

[63] Ibid., 121.

[64] Alister McGrath, The Genesis of Doctrine (Various: William B. Eerdmans Publishing Co and Regent College Publishing, 1990), 46.

[65] Ibid., 37.

[66] Kevin J. Vanhoozer, The Drama of Doctrine (Louisville, KY: Westminster John Knox Press, 2005), 166.

[67] Alister E. McGrath, Scientific Theology : Volume 3: Theory (T \& T Clark: London, 2003), 66.

[68] Anthony C. Thiselton, The Hermeneutics of Doctrine (Grand Rapids, MI; Cambridge: Wm. B. Eerdmans Publishing Co, 2007), 21-2.

[69] Thomas S. Kuhn, The Structure of Scientific Revolutions, 4th ed. (Chicago: The University of Chicago Press, 2012), 176.

[70] Kevin J. Vanhoozer, The Drama of Doctrine (Louisville, KY: Westminster John Knox Press, 2005), 165.

[71] Ibid., 165. Quoting Stephen C. Barton New Testament Interpretation as Performance. Scottish Journal of Theology 52(2), 140, 1999.

[72] Thomas S. Kuhn, The Essential Tension (Chicago and London: The University of Chicago Press, 1977), 301.

[73] Malcom B. Yarnell III, The Formation of Christian Doctrine (Nashville, TN: B \& H Academic, 2007), 102.

[74] Alister McGrath, The Genesis of Doctrine (Various: William B. Eerdmans Publishing Co and Regent College Publishing, 1990), 188.

[75] Thomas S. Kuhn, The Structure of Scientific Revolutions, 4th ed. (Chicago: The University of Chicago Press, 2012), 40.

[76] Alister E. McGrath, Scientific Theology : Volume 3: Theory (T \& T Clark: London, 2003), 68.

[77] Ibid., 75.

[78] Alister McGrath, The Genesis of Doctrine (Various: William B. Eerdmans Publishing Co and Regent College Publishing, 1990), 67.

[79] Thomas S. Kuhn, The Structure of Scientific Revolutions, 4th ed. (Chicago: The University of Chicago Press, 2012), xxxiv-v.

[80] Rhyne R. Putnam, In Defense of Doctrine: Evangelicalism, Theology and Scripture (Minneapolis, MN: Fortress Press, 2015), 230-1.

[81] Ibid., 231.

[82] Ibid., 233.

[83] Ibid., 233.

[84] Ibid., 233.

[85] Ibid., 249.

[86] Ibid., 309-10.

[87] Ibid., 310-1.

[88] Vanhoozer does admit that these relative weightings may not be agreed to by everyone.

[89] Kevin J. Vanhoozer, The Drama of Doctrine (Louisville, KY: Westminster John Knox Press, 2005), 152-3.

[90] Ibid., 152-3.

[91] Anthony C. Thiselton, The Hermeneutics of Doctrine (Grand Rapids, MI; Cambridge: Wm. B. Eerdmans Publishing Co, 2007), 21-2. 